\title{
Homegardens in a micro-regional scale: contributions to agrobiodiversity conservation in an urban-rural context
}

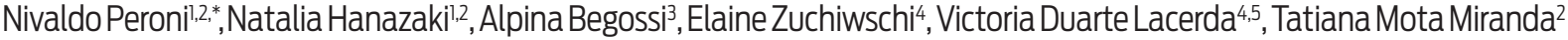

\begin{abstract}
Homegardens are conservation units for native plants and reservoirs of exotic species from different origins. We analysed the species composition and diversity of edible plants on three groups of homegardens in a gradient from urban to rural situations, but under the same historical and cultural contexts, and verified how these homegardens can favour the conservation of plants from different origins. The size of each homegarden was measured and complete inventories were carried out to assess the total edible plant diversity. Plants were collected for taxonomic identification or identified in the field, and were classified for their biogeographic origin. We compared species richness and diversity among the groups of homegardens (urban, periurban and rural), and analysed their floristic similarity. A total of 109 homegardens were studied (39 urban, 60 periurban, and 10 rural). We registered a total of 101 species, 45 botanical families and 41 varieties, with $71 \%$ of the species occurring in less than $10 \%$ of the homegardens. Rural homegardens were more diverse than periurban ones, and periurban and urban homegardens are equally diverse. We found a low but significant correlation between floristic similarity and geographic distance to the urban area. Most plants were introduced, with different origins, especially from South America Lowlands. A significant amount of plants were exchanged between relatives and neighbours. These homegardens can be considered agrobiodiversity reservoirs in a micro-regional scale, being important areas for in situ and on farm conservation and including native and exotic plants.
\end{abstract}

Keywords: Atlantic forest, ethnobotany, edible plants, urban gardens, migration.

\section{INTRODUCTION}

Homegardens are places spatially defined for plant cultivation near the houses, which can be considered as sustainable systems in an ecological perspective, since they include attributes of ecological diversity important for sustainability (Alcorn 1990; Fernandes and Nair 1986; Padoch and De Jong 1991; Smith 1996a,b). Homegardens are microenvironments with high diversity of species, varieties and genes, which constitute important sources of food, fuel, medicines, spices and construction material in many parts of the world (Eyzaguirre and Watson 2001). The structure, composition and diversity of homegardens result from the influence of socioeconomic factors, as well as

1 Department of Ecology and Zoology, Center of Biological Sciences, Universidade Federal de Santa Catarina, Campus Trindade, Florianópolis, SC, 88010-970, Brazil

2 Post Graduation Programme in Ecology, Universidade Federal de Santa Catarina, Campus Trindade, Florianópolis, SC, 88010-970, Brazil

3 CAPESCA/UNICAMP, Campinas, SP; Fisheries and Food Institute (FIFO), Ecomar/UNISANTA Santos, SP, Brazil.

4 Fundação do Meio Ambiente do Estado de Santa Catarina, Rua Felipe Schmidt \#485, Centro, Florianópolis, SC, 88010-001, Brazil

5 Doutorado em Território, Risco e Políticas Públicas - Universidade de Aveiro.

* Corresponding author. E-mail addresses: NP (nivaldo.peroni@ufsc.br, peronin@gmail.com), NH (natalia@ccb.ufsc.br), AP (alpinab@ uol.com.br), EZ (ezuchws@yahoo.com.br),VDL (victorialacerda@gmail.com),TMM (tmotamiranda@gmail.com) 
cultural values of the human groups who maintain them (Eyzaguirre and Watson 2001). Homegardens are influenced by surrounding geography and ecology, history of local occupation and by the economy and origin of the families who keep them (Blanckaert et al. 2004; Kehlenbeck and Maass 2004; Sunwar et al. 2006).

Their socio-economic and ecological functions, as well as their importance are subject of investigation in different parts of the world. In Nepal, homegardens are crucial for maintenance of household food supply, dietary diversity and health value (Sthapit et al. 2004). In Cuba, they contribute to strengthening social-ecological resilience (Buchmann 2009). In the Iberian Peninsula homegardens have a role in germplasm networks (Reyes-Garcia et al. 2013). Nineteen ecosystems' functions and related services promoted by homegardens in Catalan Pyrenees were identified (Calvet-Mir et al. 2012), including functions beyond food production, situation also reported by Robert Netting on his studies conducted with smallholders in Swiss Alps (Netting 1977). Also, homegardens can have a role as alternative spaces for cultivation inside an urban grid, linking rural and urban spaces (Heckler 2004; Winklerprins 2002).

In an urban agriculture context, homegardens can be analogous to dynamic germplasm banks, representing places for species maintenance with continuous use and management (Kumar and Nair 2004). In spite of this, the risks of the urban homegardens being reduced in its size are associated to threats to the diversity cultivated only in homegardens (Amorozo 2004). In urban areas, homegardens are spaces located inside a fragmented landscape, whose dimensions are strictly dependent on the local infrastructure (Gaston et al. 2005). Recent studies have also stressed the dynamic context of homegardens, either in its sense of species flow or as spaces for maintenance of domestication actions (Eyzaguirre and Watson 2001; Kumar and Nair 2004; Smith 1996b; Winklerprins 2002).

The influence of urbanization in the structure of homegardens has been addressed in different contexts, with growing interest since approximately $60 \%$ of the world population will be living in urban areas until 2030 (United Nations 2004).
Access to urban markets as an influence in the composition and structure of homegardens was also investigated in a rural area in Bangladesh (Shajaat Ali 2005). In Niger, higher diversities of species were present in large periurban gardens (Bernholt et al. 2009). Based on the notion that the increasing urbanization accelerates the loss of biodiversity and displaces native species, a study in São Luís, North Brazil (Akinnifesi et al. 2010) showed that the urban areas might serve as a repository of indigenous species, including those with risk of disappearance in the wild.

In a conservation context, homegardens are pointed as potential areas for practicing in situ and on farm conservation (Galluzzi et al. 2010; Watson and Eyzaguirre 2001) either in rural and urban areas. In addition to the functions previously discussed, homegardens are understood as resources reservoir areas, with plants with worldwide origin, and also can represent a "space of resistance" against a trend towards the agricultural homogeneity (Amorozo 2004; Brodt 2001; Das and Das 2005) and also against local knowledge loss.

Brazilian homegardens have been studied mainly in Amazon context, usually with the predominance of an analogy between homegardens and agroforestry systems (Alcorn 1990; Anderson et al. 1985; Guillaumet et al; 1990; Smith 1996b). Homegardens are also relevant due to the importance of traditional plant management systems, in which they can be strongly related to food security. Outside the Amazon context, on regions called considered as "orphan eco-regions" (Albuquerque et al. 2005), where the forest context is less complex or absent, there are few studies analysing homegardens in other ecological and socio-economic contexts, or with non-forest indigenous peoples. On Atlantic coast, for example, there are few studies about homegardens managed by fisher-farmers, in spite of several studies about ethnobotany of artisanal fishers (Begossi et al. 2002; Hanazaki et al. 2009; Peroni et al. 2008).

In coastal areas we observe an increasing urbanization pressure, driving changes in the former fisher-farmer communities towards urbanized or periurbanized communities. In this perspective, is crucial to understand how homegardens can contribute to resource conservation of plants with 
distinct origins and under different degrees of urbanization. Although there is a general idea that agrobiodiversity can decrease from rural to urban homegardens, Poot-Pool et al. (2015) argued in a Mexica region the periurban homegardens combined fruit trees with a high diversity of ornamental herbs, while rural and semi-rural homegardens kept tree and shrub species of distinct uses, cultivated less ornamental species and had a larger native component than periurban homegardens. In order to contribute to the knowledge on the role of home gardens in the conservation of agricultural biodiversity, we selected an area adjacent to the Atlantic Forest coast with the objective of verify how the diversity of edible plants maintained in homegardens is affected by their distinct degree of urbanization. We address the following questions related to urbanization and in situ conservation in homegardens: 1) Do the characteristics of the homegardens such as species diversity and composition vary in relation to their proximity to urban infrastructures?; 2) Do the proportions of native and introduced species varies from rural to urban homegardens? When we address these questions, we also aimed to discuss how homegardens can contribute to plant conservation in the context of urbanization; and whether homegardens can be considered a reservoir of plants from distinct origins.

\section{MATERIAL AND METHODS}

\section{Study area}

This study was conducted in the Island of Santa Catarina, Brazil. This island comprises part of Florianópolis municipality, between the coordinates $27^{\circ} 25^{\prime}-27^{\circ} 50^{\prime} \mathrm{S}$ and $048^{\circ} 25^{\prime}-048^{\circ} 35^{\prime} \mathrm{W}$, within the Atlantic Forest Domain. The estimated municipality population is around 450,000 inhabitants (IBGE 2016), distributed in an area with a higher amount of Atlantic Forest remnants, offering a situation that overlaps the urban occupation with the forest fragments.

Traditional communities of fisher-farmers historically occupied most of the Brazilian Atlantic Coast, with different degrees of cultural influenc- es from Amerindians, European colonists and Africans. In the studied area there is a remarkable influence of Azorean colonists from the 18th century immigration (Lago 1996). A distinctive Azorean way of living lasted until the middle of 20th century (Lago 1996). After this period, the urbanization of the municipality has been growing rapidly. The studied communities are located in the southern part of the island, about $40 \mathrm{~km}$ far from the centre of the city, where we can identify a urbanization gradient based in the infrastructure and access to the communities. We selected three representative areas with different degrees of urbanization: 1) Pântano do Sul is the urban area (URB); 2) Costa de Dentro and Costa de Cima, both situated in an intermediate area, were the periurban (PER); and 3) Sertão do Ribeirão is the rural area (RUR). Pântano do Sul is one of the more traditional artisanal fisher communities in Santa Catarina island, however it was urbanized since the arrival of electricity, the paving of the roads, and the increasing of the tourism. In the other extreme, Sertão do Ribeirão is one of the few places in Santa Catarina island which still maintain rural characteristics, and is known for its traditional manioc flour and sugarcane liquor mills. Between these two areas, Costa de Dentro and Costa de Cima share characteristics with both Pântano do Sul and Sertão do Ribeirão.

The URB and PER areas are situated in the same district, called Pântano do Sul, and its total population is estimated around 5,000 inhabitants (SIDRA 2016). URB has a spatial arrangement in irregular blocks, with all streets and alleys paved. The urban structure consists in small markets, an elementary school, restaurants and bars, as well as tourist's houses. This community is located by the sea and the main livelihoods include retired people, fishers, autonomous workers, public workers, and commerce owners. PER is arranged along an unpaved road with distances varying from $1 \mathrm{~km}$ up to $2.5 \mathrm{~km}$ from URB. Local livelihoods include retired people, autonomous workers, public workers, housekeepers, masons, farmers and day wage jobs. This area is becoming gradually inserted into an urban context, being apart from the beach but in direct contact with the urban structure that surrounds them, including roads, urban transport, and small markets. RUR is one of the last remnants of a 
rural area within Santa Catarina Island and is constituted by a small community, with approximately 140 inhabitants (Pereira 2001). It is located in the middle of the island with difficult access through unpaved roads, which can be not passable during the rainy season. The distance to urban areas varies between $2 \mathrm{~km}$ and $8 \mathrm{~km}$ far. All households practice some cultivation (Batista 2004; Pereira 2001), and about half of the inhabitants are retired.

\section{Data collection}

We visited all homegardens in each area and interviewed the owners after obtaining their prior informed consent. At the time of data collection the Ethics Committee on Research with Human Beings of Universidade Federal de Santa Catarina did not require the submission of projects with interviews (expect for indigenous people). We used a structured questionnaire, including questions about the age of the interviewee, years of residence in the community, how many residents the household had, and questions about the uses of the species found in the homegardens. For each species we asked about the management practices, if the plant was cultivated or spontaneous, how the plant was obtained, what was the origin of each plant, from where it was collected, and whether the respondent had already given to someone seeds or seedlings of that plant. The size of each homegarden was measured using a GIS database (IPUF 20092016), excluding the area occupied by the house. Geographic distances between the areas were estimated though the GIS database. Complete inventories were carried out to assess the total plant richness, regarding both species and varieties, and the abundance of crop species. We considered crop species those used for food, as well as those used for seasonings and as non-medicinal teas. Whenever possible the plants were identified in the field. Plants collected for taxonomic identification were deposited at EAFM Herbarium (Instituto Federal de Educação, Ciência e Tecnologia do Amazonas), voucher numbers 393 to 416/LEHE. We classified the plants present in homegardens as native or introduced, according with specific literature research for each species (Badouin and Lebrun 2009; Baldoni et al. 2006; Breton et al. 2008;
Brücher 1989; De Vries 1997; lorizzo et al. 2013; Janoo et al. 1999; Jatoi et al. 2008; Kiær et al. 2009; Lorenzi 1992a,b,c; MOBOT 2016; Nakata et al. 2005; Paton and Putievsky 1996; Pickersgill 2007; Prance and Nesbitt 2005; Rodrígues-Ariza and Moya 2005; Sanjur et al. 2002; Vieira et al. 2001). We considered native those species present in the Neotropics before 1492, or in pre-Columbian times (Clement 1999; Prance and Nesbitt 2005). Introduced species were those that were brought to Neotropics after 1492 (Clement 1999; Prance and Nesbitt 2005). We also classified the plants according with Vavilov's area of origin: I Chinese (East Asia), II Indian (South and Southwest Asia, India, and Malasia), III Inner Asiatic (Central Asia), IV Asia Minor (Middle East), $\mathrm{V}$ Mediterranean (Mediterranean and region between Asia and Europe), VI Ethiopian (Africa), VII South Mexican/Central American (Mesoamerica), VIII South American Andean (Andenean), VIIla Chilean, VIIIb Brazilian-Paraguayan (Vavilov 1992). We added to this classification one species from Oceania. Besides knowing that Meyer et al. (2012) proposed a new interpretation about Vavilov's theory, we choose for the classic approach due to its wide acceptance. Data was collected between 2008 and 2009.

\section{Data Analysis}

Data was analyzed according to the gradient of urbanization of the three studied areas. For comparison of the species richness in each area, we analysed the sample-based accumulation curves using the software EcoSim version 7.72 (Gotelli and Entsminger 2011). This analysis allowed us to compare the richness between areas. We calculated for each area mean estimated richness and standard deviation, and differences were tested through Kruskal-Wallis H-Test. Species diversity was analysed through richness accumulation curves and PIE index (Gotelli and Entsminger 2011). We used PIE index because it enables the comparison of samples with different sizes. We compared floristic similarity among the three areas through Sørensen coefficient, and we used Spearman's correlation to investigate the relation between floristic similarity and geographic distance between homegardens at a microregional level. The average number of plants 
in each life form was tested through Kruskal-Wallis $\mathrm{H}$-Test. The proportion of native and exotic species was calculated as percentages of native and exotic species present in each group of homegardens (urban, periurban, and rural).

\section{RESULTS AND DISCUSSION}

Periurban (PER) homegardens are maintained by younger people, living there for 12 years, on average, in opposite to rural (RUR) and urban (URB) ones, maintained by older and people by those inhabitants with more time in the communities (Table 1). Considering the available area for use, the mean size of the homegardens varied among the three studied areas. These mean areas are very close to homegardens in urban and rural areas in Belém, in Brazilian Amazon (Madaleno 2000). There is less variation in the size of the homegardens at URB when compared to RUR and PER. Urban homegardens are smaller (mean $\left.281 \mathrm{~m}^{2}\right)$, followed by rural $\left(324 \mathrm{~m}^{2}\right)$, and periurban $(593 \mathrm{~m} 2)$, where we found a homegarden with an area of $3,748 \mathrm{~m}^{2}$ (Table 1). This clear trend toward smaller homegardens in urban areas was also found for Amazonian urban homegardens in Belém (Winklerprins 2002), yet the studied homegardens are smaller than those studied in Brazilian Amazon (Madaleno 2000; Winklerprins 2002). Although presenting the highest mean size, periurban homegardens are smaller in proportion (33\% of plot area was occupied with homegarden), if compared with the rural ones $173 \%$ of plot area with homegarden). Particularly at URB the area reserved for homegardens can be even more reduced. Many people are losing their homegarden cultivation habits, and several areas formerly destined to homegardens were being covered with impermeable materials, such as cement or paving tiles. In a sub-sample of 15 URB households, we observed that the homegarden could be reduced up to $80 \%$ of its originally available area, over the years. In spite of the differences on mean plot areas being three times higher at PER, the homegardens areas in URB and RUR were similar (Table 1).

Table 1. Households and homegardens characteristics in Santa Catarina Island, Brazil.

\begin{tabular}{l|l|l|l|l|l|l}
\hline \multirow{2}{*}{ Areas/Characteristics } & \multicolumn{3}{|c|}{ Urban } & \multicolumn{2}{c|}{ Periurban } & \multicolumn{2}{c}{ Rural } \\
\cline { 2 - 8 } & Mean & Range & Mean & Range & Mean & Range \\
\hline Household head age (years) & 53 & $20-88$ & 46 & $18-70$ & 54 & $30-76$ \\
\hline Years of the residence & 24 & $1-67$ & 12 & $1-50$ & 32 & $8-60$ \\
\hline Total plot area $\left(\mathrm{m}^{2}\right)$ & 431 & $144-1,092$ & 1681 & $84-33,800$ & 394 & $150-800$ \\
\hline Homegarden size $\left(\mathrm{m}^{2}\right)$ & 281 & $70-717$ & 593 & $34-3,748$ & 324 & $49-752$ \\
\hline Plot area with homegarden $(\%)$ & 63 & $29-89$ & 33 & $2-72$ & 73 & $35-94$ \\
\hline N studied homegardens & 39 & & 60 & & 10 & \\
\hline
\end{tabular}

\section{Floristic composition and diversity of the species}

A total of 101 food species were recorded in the 109 homegardens, belonging to 80 genera and 45 botanical families. In an infraspecific level, eight species presented a total of 41 varieties (Table 2). The total species richness is higher than other high-diversity regions, such as Manaus (Brazilian Amazonia), where 79 species for food and season- ings were found in 16 homegardens (Major et al. 2005). In Belém, 46 species were found in 40 urban and rural homegardens (Winklerprins 2002), and 36 species were found in Piaroa homegardens, Venezuelan Amazon (Heckler 2004). In Rio Branco, Brazilian Amazon, 77 food species were recorded in 132 urban homegardens (Siviero et al. 2011). In an area of transition between savannah and rainforest, in 17 urban homegardens 98 food species were registered (Eichemberg et al. 2009). 
Table 2. Edible plant species found in 109 homegardens at Santa Catarina Island, Brazil.

\begin{tabular}{|c|c|c|c|c|}
\hline FAMILY / Species & Portuguese name $^{a}$ & Origin $^{b}$ & Life form ${ }^{c}$ & $\%$ \\
\hline \multicolumn{5}{|l|}{ ANACARDIACEAE } \\
\hline Mangifera indica L. & Manga & II & Tree & 12 \\
\hline Spondias purpurea L. & Seriguela & VII & Tree & 2 \\
\hline \multicolumn{5}{|l|}{ ANNONACEAE } \\
\hline Annona squamosa $\mathrm{L}$. & Fruta-do-conde & VII & Tree & 6 \\
\hline \multicolumn{5}{|l|}{ APIACEAE } \\
\hline Daucus carota L. & Cenoura & III & Herb & 4 \\
\hline Foeniculum vulgare Gaertn. & Erva-doce & V & Herb & 6 \\
\hline Petroselinum crispum (Mill.) Nyman ex A. W. Hill & Salsinha & $\mathrm{V}$ & Herb & 6 \\
\hline \multicolumn{5}{|l|}{ ARACEAE } \\
\hline Xanthosoma sp.2 & Inhame & VIIIb & Herb & 2 \\
\hline Xanthosoma sagittifolium (L.) Schott & Taiá & VIIIb & Herb & 6 \\
\hline \multicolumn{5}{|l|}{ ARECACEAE } \\
\hline Archontophoenix alexandraeWendl. \& Drude & Palmeira-real & Oceania & Palm & 1 \\
\hline Butia capitata Beccari & Butia & VIIIb & Palm & 3 \\
\hline Cocos nucifera L. & Coco-da-bahia & II & Palm & 3 \\
\hline Euterpe edulis Mart. & Palmito & VIIIb & Palm & 6 \\
\hline Syagrus romanzoffiana (Cham.) Glassman & Coquinho & VIIIb & Palm & 1 \\
\hline \multicolumn{5}{|l|}{ ASTERACEAE } \\
\hline Mikania sp. & Guaco & VIIIb & Herb & 1 \\
\hline Cichorium endivia L. & Chicoria & $\mathrm{V}$ & Herb & 1 \\
\hline Cichorium intybus $\mathrm{L}$. & Radiche & $\mathrm{V}$ & Herb & 1 \\
\hline Lactuca sativa L. & Alface & IV & Herb & 14 \\
\hline Matricaria chamomilla L. & Camomila & V & Herb & 4 \\
\hline \multicolumn{5}{|l|}{ BIXACEAE } \\
\hline Bixa orellana L. & Urucum & VIIIb & Tree & 4 \\
\hline \multicolumn{5}{|l|}{ BRASSICACEAE } \\
\hline Brassica oleracea L. & Couve (3) & $\mathrm{V}$ & Herb & 24 \\
\hline Eruca sativa Mill. & Rucula & $\mathrm{V}$ & Herb & 1 \\
\hline Raphanus sativus L. & Rabanete & V & Herb & 1 \\
\hline \multicolumn{5}{|l|}{ BROMELIACEAE } \\
\hline Ananas comosus (L.) Merr. & Abacaxi & VIIIb & Herb & 4 \\
\hline \multicolumn{5}{|l|}{ CARICACEAE } \\
\hline Carica papaya L. & Mamao & VII & Tree & 28 \\
\hline \multicolumn{5}{|l|}{ CHENOPODIACEAE } \\
\hline Beta vulgaris $\mathrm{L}$. & Beterraba & V & Herb & 7 \\
\hline \multicolumn{5}{|l|}{ CLUSIACEAE } \\
\hline Garcinia gardneriana (Planch. \&Triana) D.Zappi & Bacupari & VIIIb & Tree & 1 \\
\hline \multicolumn{5}{|l|}{ CONVOLVULACEAE } \\
\hline Ipomoea batatas (L.) Lam & Batata doce & VIIIb & Herb & 6 \\
\hline \multicolumn{5}{|l|}{ CUCURBITACEAE } \\
\hline Citrullus lanatus (Thunb.) Matsumura \& Nakai & Melancia & $\mathrm{VI}$ & Herb & 1 \\
\hline Cucumis melo L. & Melão & VI & Herb & 1 \\
\hline
\end{tabular}




\begin{tabular}{|c|c|c|c|c|}
\hline FAMILY / Species & Portuguese name ${ }^{a}$ & Origin $^{b}$ & Life form ${ }^{c}$ & $\%$ \\
\hline Cucumis sativus $\mathrm{L}$. & Pepino & III & Herb & 2 \\
\hline Cucurbita maxima Duchesne & Abobora & VIIIlb & Herb & 14 \\
\hline Cucurbita pepo L. & Abobrinha & VII & Herb & 1 \\
\hline Sechium edule (Jacq.) Sw. & Chuchu & VII & Herb & 15 \\
\hline \multicolumn{5}{|l|}{ DIOSCOREACEAE } \\
\hline Dioscorea sp. & Cará & $\mathrm{VI}$ & Herb & 2 \\
\hline \multicolumn{5}{|l|}{ EBENACEAE } \\
\hline Diospyros kaki L. & Caqui & 1 & Tree & 8 \\
\hline \multicolumn{5}{|l|}{ ERICACEAE } \\
\hline Vaccinium sp. & Mirtilo & VII & Shrub & 1 \\
\hline \multicolumn{5}{|l|}{ EUPHORBIACEAE } \\
\hline Manihot esculenta Crantz & Aipim (4) & VIIIlb & Shrub & 20 \\
\hline \multicolumn{5}{|l|}{ FABACEAE } \\
\hline Arachis hypogaea L. & Amendoim & VIIIlb & Herb & 2 \\
\hline Cajanus cajan (L.) Mill. & Feijão-guandú & II & Herb & 2 \\
\hline Phaseolus vulgaris $\mathrm{L}$. & Feijao & VIII & Herb & 5 \\
\hline \multicolumn{5}{|l|}{ LAMIACEAE } \\
\hline Cunila spicata $\mathrm{L}$. & Poejo & VIIIIb & Herb & 3 \\
\hline Melissa officinalis L. & Erva-cidreira & $\mathrm{V}$ & Shrub & 1 \\
\hline Mentha sp1 & Hortela & V & Herb & 30 \\
\hline Mentha sp2. & Menta & V & Herb & 2 \\
\hline Ocimum basilicum $\mathrm{L}$. & Alfavaca & $\mathrm{Nd}$ & Shrub & 5 \\
\hline Ocimum gratissimum L. & Alfavaca & $\mathrm{VI}$ & Shrub & 28 \\
\hline Ocimum sp. & Manjericao & $\mathrm{Nd}$ & Shrub & 21 \\
\hline Origanum majorana L. & $\begin{array}{l}\text { Manjerona } \\
\text { (Manjericão) }\end{array}$ & V & Shrub & 3 \\
\hline Origanum sp. & Orégano & $\mathrm{V}$ & Shrub & 10 \\
\hline Origanum vulgare $\mathrm{L}$. & Orégano & $\mathrm{V}$ & Shrub & 3 \\
\hline Rosmarinus officinalis L. & Alecrim & V & Shrub & 23 \\
\hline \multicolumn{5}{|l|}{ LAURACEAE } \\
\hline Laurus nobilis L. & Louro & $\mathrm{V}$ & Tree & 4 \\
\hline Persea americana Mill. & Abacate & VII & Tree & 16 \\
\hline \multicolumn{5}{|l|}{ LILIACEAE } \\
\hline Allium cepa L. & Cebola & III & Herb & 10 \\
\hline Allium sativum $\mathrm{L}$. & Alho & IV & Herb & 4 \\
\hline \multicolumn{5}{|l|}{ MAGNOLIACEAE } \\
\hline Illicium verum Hook & Anis-estrelado & 1 & Shrub & 3 \\
\hline \multicolumn{5}{|l|}{ MALPIGHIACEAE } \\
\hline Bunchosia armeniaca (Cav.) DC. & Guaraná & VIII & Tree & 3 \\
\hline Malpighia glabra L. & Acerola & VII & Tree & 17 \\
\hline \multicolumn{5}{|l|}{ MIMOSACEAE } \\
\hline Inga sp. & Inga & VIIIb & Tree & 4 \\
\hline
\end{tabular}




\begin{tabular}{|c|c|c|c|c|}
\hline FAMILY / Species & Portuguese name $^{a}$ & Origin $^{\mathrm{b}}$ & Life form ${ }^{\mathrm{c}}$ & $\%$ \\
\hline \multicolumn{5}{|l|}{ MORACEAE } \\
\hline Artocarpus heterophyllus Lam. & Jaca & II & Tree & 2 \\
\hline Artocarpus sp. & Fruta-pão & II & Tree & 1 \\
\hline Ficus carica $\mathrm{L}$. & Figo & IV & Tree & 2 \\
\hline Morus nigra L. & Amora & 1 & Tree & 7 \\
\hline \multicolumn{5}{|l|}{ MUSACEAE } \\
\hline Musa section Musa & Banana (12) & II & Tree & 55 \\
\hline \multicolumn{5}{|l|}{ MYRTACEAE } \\
\hline Campomanesia xanthocarpa O. Berg & Gabiroba & VIIIlb & Tree & 1 \\
\hline Eugenia brasiliensis Lam. & Grumixama & VIIIlb & Tree & 3 \\
\hline Eugenia jambos L. & Jambolão & II & Tree & 1 \\
\hline Eugenia tomentosa Aubl. & Cabeludinha & VIIIIb & Tree & 4 \\
\hline Eugenia uniflora L. & Pitanga & VIIIlb & Tree & 25 \\
\hline Myrciaria cauliflora Berg. & Jaboticaba & VIIIlb & Tree & 20 \\
\hline Myrtaceae sp.1 & Erva-pra-suco & VIIIlb & Tree & 1 \\
\hline Psidium cattleyanum Sabine & Araca & VIIIlb & Tree & 11 \\
\hline Psidium guajava L. & Goiaba (2) & VIIIlb & Tree & 41 \\
\hline \multicolumn{5}{|l|}{ OLEACEAE } \\
\hline Olea europaea L. & Azeitona & $\mathrm{V}$ & Tree & 1 \\
\hline \multicolumn{5}{|l|}{ OXALIDACEAE } \\
\hline Averrhoa carambola L. & Carambola & II & Tree & 4 \\
\hline \multicolumn{5}{|l|}{ PASSIFLORACEAE } \\
\hline Passiflora alata Curtis & Maracujá-de-cobra & VIIIlb & Liana & 1 \\
\hline Passiflora edulis Sims. & Maracuja-doce & VIIIlb & Liana & 30 \\
\hline \multicolumn{5}{|l|}{ POACEAE } \\
\hline Cymbopogon citratus (DC.) Stapf & Capim limao & II & Herb & 2 \\
\hline Saccharum officinarum L. & Cana & II & Herb & 15 \\
\hline Zea mays $\mathrm{L}$. & Milho & VII & Herb & 6 \\
\hline \multicolumn{5}{|l|}{ PUNICACEAE } \\
\hline Punica granatum L. & Roma & IV & Tree & 3 \\
\hline \multicolumn{5}{|l|}{ ROSACEAE } \\
\hline Rosaceae sp.1 & Ameixa-pará & $\mathrm{Nd}$ & Tree & 1 \\
\hline Rubus sp. & Amora & $\mathrm{Nd}$ & Shrub & 1 \\
\hline Eriobotrya japonica Lindl. & Ameixa & 1 & Tree & 25 \\
\hline Fragaria vesca L. & Morango & VIIlla & Herb & 2 \\
\hline Malus domestica P. Mill. & Macieira & IV & Tree & 2 \\
\hline Prunus persica (L.) Sieb. \& Zucc. & Pessego & 1 & Tree & 9 \\
\hline Pyrus communis $\mathrm{L}$. & Pera & III & Tree & 3 \\
\hline \multicolumn{5}{|l|}{ RUBIACEAE } \\
\hline Coffea arabica L. & Café & $\mathrm{VI}$ & Tree & 10 \\
\hline Coffea sp. & Café-caturra & $\mathrm{VI}$ & Tree & 1 \\
\hline \multicolumn{5}{|l|}{ RUTACEAE } \\
\hline Citrus limonia & Limao (6) & II & Tree & 6 \\
\hline
\end{tabular}




\begin{tabular}{l|l|l|l|l}
\hline FAMILY / Species & Portuguese name & O & Origin & Life form \\
\hline Citrus reticulata Blanco & Bergamota & II & Tree & 35 \\
\hline Citrus sinensis (L.) Osbeck & Laranja (9) & II & Tree & 36 \\
\hline Citrus sp. & Limao (3) & II & Tree & 45 \\
\hline SAPOTACEAE & & & & \\
\hline Sapota zapotilla (Jacq.) Cov & Sapoti & VII & Tree & 1 \\
\hline SOLANACEAE & & & & \\
\hline Capsicum annuum L. & Pimentão & VII & Herb & 5 \\
\hline Capsicum sp. & Pimenta & VII & Herb & 14 \\
\hline Lycopersicon esculentum Mill. & Tomate (2) & VIII & Herb & 16 \\
\hline Solanum melongena L. & Berinjela & II & Herb & 2 \\
\hline VITACEAE & & & & \\
\hline Vitis vinifera L. & Uva-moscatel & IV & Liana & 7 \\
\hline ZINGIBERACEAE & & & & \\
\hline Zingiber officinale Roscoe & Gengibre & II & Herb & 6 \\
\hline
\end{tabular}

a number of varieties in parenthesis; ${ }^{b}$ Roman numbers indicate Vavilov' species centre of origin [60]: I Chinese; II Indian; III Inner Asiatic; IV Asia Minor; V Mediterranean; VI Ethiopian; VII South Mexican/Central American (Mesoamerica); VIII South American Andean (Andean); VIIla Chilean (one specie); VIIIb Brazilian-Paraguayan, nd=no data; ${ }^{c}$ Herb=herbaceous; \% cultivation frequency

In the present study, there was a great variability among the sampled homegardens, with 72 species occurring in less than $10 \%$ of them. Unique occurrences or species in homegardens accounts for 23 species, among the 101 species registered. This situation shows the role of homegardens as important plant resources reservoirs, once they maintain rare species, as observed by other authors (Eyzaguirre and Watson 2001; Galluzzi et al. 2010).

The most frequently cultivated species was banana (Musa section Musa, present in $55 \%$ of the homegardens). Among the 16 species present up to $20 \%$ of the homegardens, other 10 were fruits, most of them perennial trees [Citrus sp., 45\%; Psidium guajava L., 41\%; Citrus sinensis (L.) Osbeck, 36\%; Citrus reticulata Blanco, 35\%; Passiflora edulis Sims., 30\%; Carica papaya L., 28\%; Eugenia uniflora L., 25\%; Eriobotrya japonica Lindl., 25\%; and Myrciaria cauliflora Berg., 20\%] and four were used as seasonings [Mentha sp., $30 \%$; Ocimum gratissimum L., 28\%; Rosmarinus officinalis L., 23\%, and Ocimum sp., 21\%]. The remaining two species were Brassica oleracea
L. (24\%), which include the coles and broccolis, commonly found in orchards, and Manihot esculenta Crantz (20\%), or sweet manioc. Musa section Musa, C. papaya and P. guajava were also the most cultivated species in Cuban homegardens (Buchmann 2009). C. papaya and Citrus were also important in old homegardens located in other Brazilian regions (Eichemberg et al. 2009; Siviero et al. 2011). We highlight the contribution of native fruits, which include several species of Myrtaceae, and some Arecaceae and Passifloraceae.

The total species richness per area is similar between PER (72 species) and RUR (71 species), contrasting with URB (54 species). Nevertheless, we may consider that the sample sizes were different due to the different size of each area. To avoid the effect of sample size we compared the species richness through accumulation curves for occurrences or citations (Figure 1), showing that the diversity for RUR homegardens was higher than for PER. However, there is no difference between the richness of PER and URB homegardens (Figure 1, Table 3). 


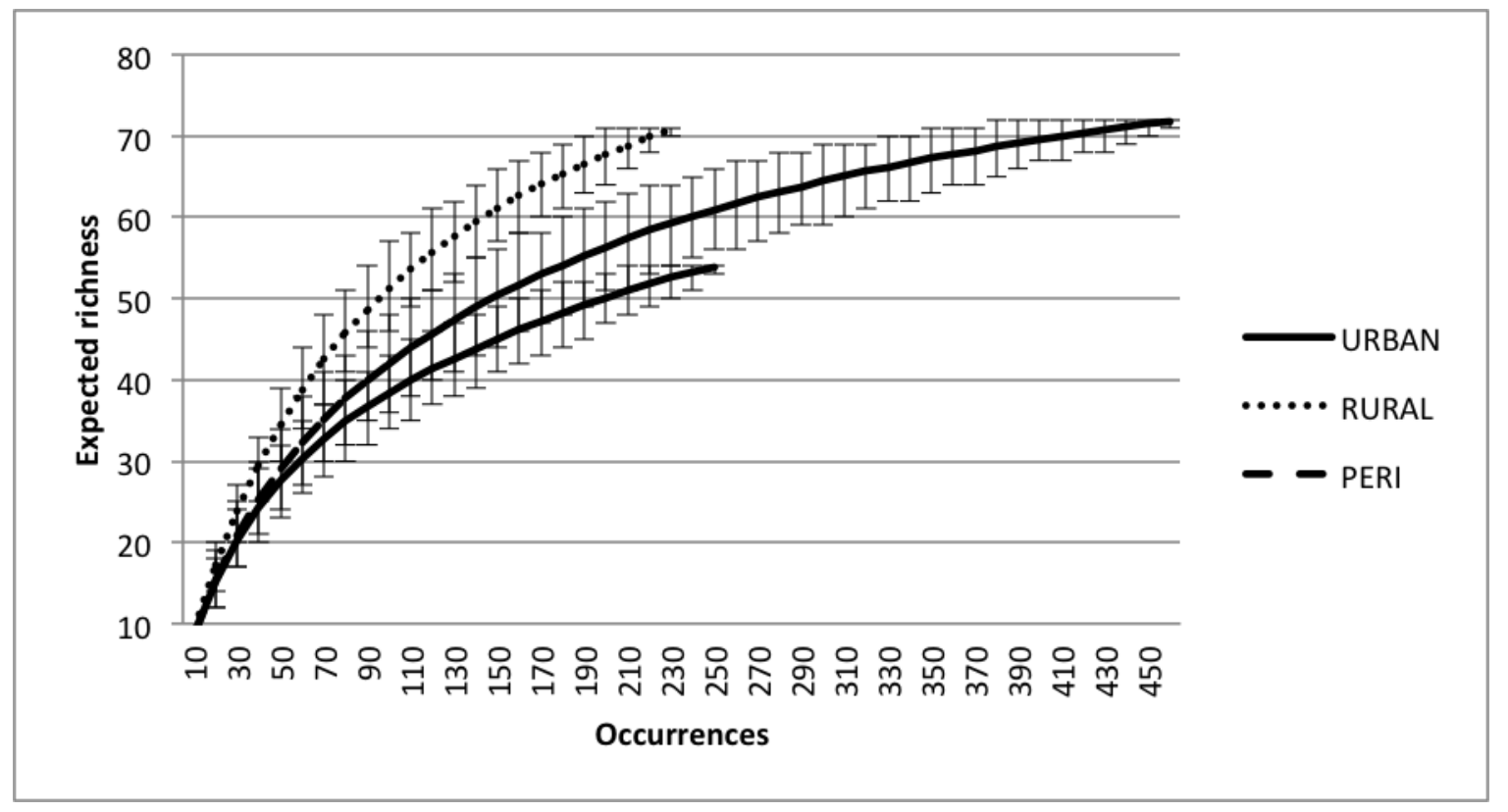

Figure 1. Accumulation curves for urban, periurban and rural homegardens at Santa Catarina Island, according to species citations ( $n=109)$. PERI = Periurban

Table 3. Diversity comparisons for rural, periurban and urban homegardens at Santa Catarina Island, Brazil ( $n=109)$.

\begin{tabular}{l|l|l|l}
\hline & Urban & Periurban & Rural \\
\hline Urban & 0.96806 & ns & $\mathrm{p}<0.05$ \\
\hline Periurban & & 0.96938 & $\mathrm{p}<0.05$ \\
\hline Rural & & & 0.98351 \\
\hline
\end{tabular}

PIE index= diagonals; $n s=$ non significative differences

The mean richness, or average number of species per homegarden, was 17.39 (sd=14.60, $\mathrm{n}=109$ ). However, the averages were different depending on the area: RUR had average richness more than three times higher than URB. The average number of species per URB homegarden was 12.82 ( $\mathrm{sd}=8.82, \mathrm{n}=39$ ), similar to PER homegardens (15.50, sd=11.32, $\mathrm{n}=60$ ) but lower than RUR (46.40, $s d=18.47, n=10$ ) (Kruskall-Wallis $H=22.40$, $\mathrm{p}<0.0001)$.

According to our expectation, URB homegardens maintain less diversity than RUR and PER, and this can be a consequence of their small size. Diversity can be directly influenced by the size of the homegarden (Lamont et al. 1999). Socioeconomic factors such as the main economic activities of the homegardens owners can also play an expressive effect in the diversity maintained in these areas, once we expect that in URB people have less time available to manage their spaces.

We observed a significant but low correlation between floristic similarity and geographic distance $(R m=0.10, p<0.02)$, showing that there is a small degree of heterogeneity between homegardens when considering the micro-regional scale. When the richness distribution between the three areas was analysed, this heterogeneity became more apparent between the RUR and URB extremes.

We observed a similar proportion of life forms (Table 4) for herbs $(40 \%)$ and trees $(41 \%)$, followed by shrubs $(12 \%)$. Elements such as palms $(4 \%)$ and lianas $(3 \%)$ are rare in the studied homegardens. Also, rural homegardens show a more plants in each life form category. Similar means of herbaceous species were found in URB and PER, differing for RUR (Kruskall-Wallis $H=22.90, p<0.0001$ ). The same differences were observed for trees: higher and different averages in RUR homegardens, and lower and similar averages in URB and PER (Kruskall-Wallis $\mathrm{H}=22.20, \mathrm{p}<0.0001$ ). 
Table 4. Average number of each life form per homegarden at Santa Catarina Island, Brazil $(n=109)$.

\begin{tabular}{l|l|l|l}
\hline & $\begin{array}{l}\text { Urban } \\
(\mathrm{S}=54)\end{array}$ & $\begin{array}{l}\text { Periurban } \\
(\mathrm{S}=72)\end{array}$ & Rural (S=71) \\
\hline Tree & $3.18(3.32)$ & $4.30(3.48)$ & $11.60(4.43)$ \\
\hline Herbaceous & $8.13(5.51)$ & $9.68(7.75)$ & $31.60(13.28)$ \\
\hline Liana & $0.23(0.48)$ & $0.37(0.55)$ & $1.10(0.99)$ \\
\hline Shrub & $1.28(1.28)$ & $1.05(1.03)$ & $1.50(1.08)$ \\
\hline Palm & $0.05(0.22)$ & $0.10(0.30)$ & $0.60(0.70)$ \\
\hline
\end{tabular}

${ }^{*}$ standard deviation in parenthesis

Trees were the most expressive strata in Vietnamese homegardens from Phong My commune (Vlkova et al 2011). The strata diversification of the plants indicates a complex architectural design of homegardens, providing a better use of the microenvironments (Galluzzi et al. 2010). In traditional Indian homegardens the process of modernization includes a decrease of the tree/ shrub diversity, and a gradual homogenization of homegarden structure (Peyre et al. 2006). If the modernization and the increasing urbanization degree influence the species grown in homegardens, a highest number of tree species could be expected for less urbanized homegardens, as we observed in this study. Rural homegardens, with larger spaces for cultivation, could have more tree elements, and urban and smaller homegardens may have optimized for herbaceous species that need smaller areas. Besides that, rural homegardens are located in more environmentally complex areas, which can contribute with high strata diversification.

\section{Plants from where? Biogeographic origin of the homegardens' agrobiodiversity}

Figure 2 shows the origin of each species found in the studied homegardens, according to Vavilov's classification (Vavilov 1992). We considered native species those with origin in the Neotropics (e.g. from South Mexican/Central America, Andes and South America Lowlands), and exotic or introduced species correspond to those species introduced in Americas after the European colonization beginning with Columbus (1492 AD) (Clement 1999;
Prance and Nesbitt 2005). In this sense, we accept that some introductions in southern Brazil can be considered as native plant species due to human migrations in pre-Columbian times, such as Zea mays L. and Manihot esculenta Crantz. Two exceptions to this classification correspond to species that were recently introduced (Vaccinium sp. and Malpighia glabra L.), based on field observations.

The majority of the species found in the homegardens were introduced (62\%) while $38 \%$ were considered native (Table 5). The use of many exotic species in traditional systems is common even in high diversity areas such as tropical forests (Hanazaki et al. 2000). We noticed that the occurrence of native plants was more expressive in rural homegardens, which can be related to the importance of the surrounding environment in the homegarden composition. RUR is located in a mosaic of areas with patches of Atlantic rainforest with different stages of succession.

Different proportions of native and exotic species were found in other Atlantic rainforest areas, yet considering plants for food, medicine, and handicrafts. In a study at the northern coast of São Paulo state, about $51 \%$ of the species were native, $37 \%$ exotic, $2 \%$ weeds and $10 \%$ undefined (Hanazaki et al. 2000). For fishing communities is usual to found a highest proportion of native species among those used for handicrafts and construction, and lowest proportions among medicine and edible plants used, once they are cultivated. Among 12 communities from Atlantic Forest, introduced species correspond to $44 \%$ of 227 medicinal species identified, while native ones correspond to 38\% (Albuquerque et al. 2005).

Considering the biogeographic regions (Figure 2), the homegardens are reservoirs of plants from different origins. Highest percentages correspond to plants from South American Lowlands, in all areas. In the general picture, URB and RUR present more contrasts than PER and URB and PER and RUR. Nonnative species coming from Asia, Mediterranean and India had higher proportions in urban homegardens (Figure 2). 


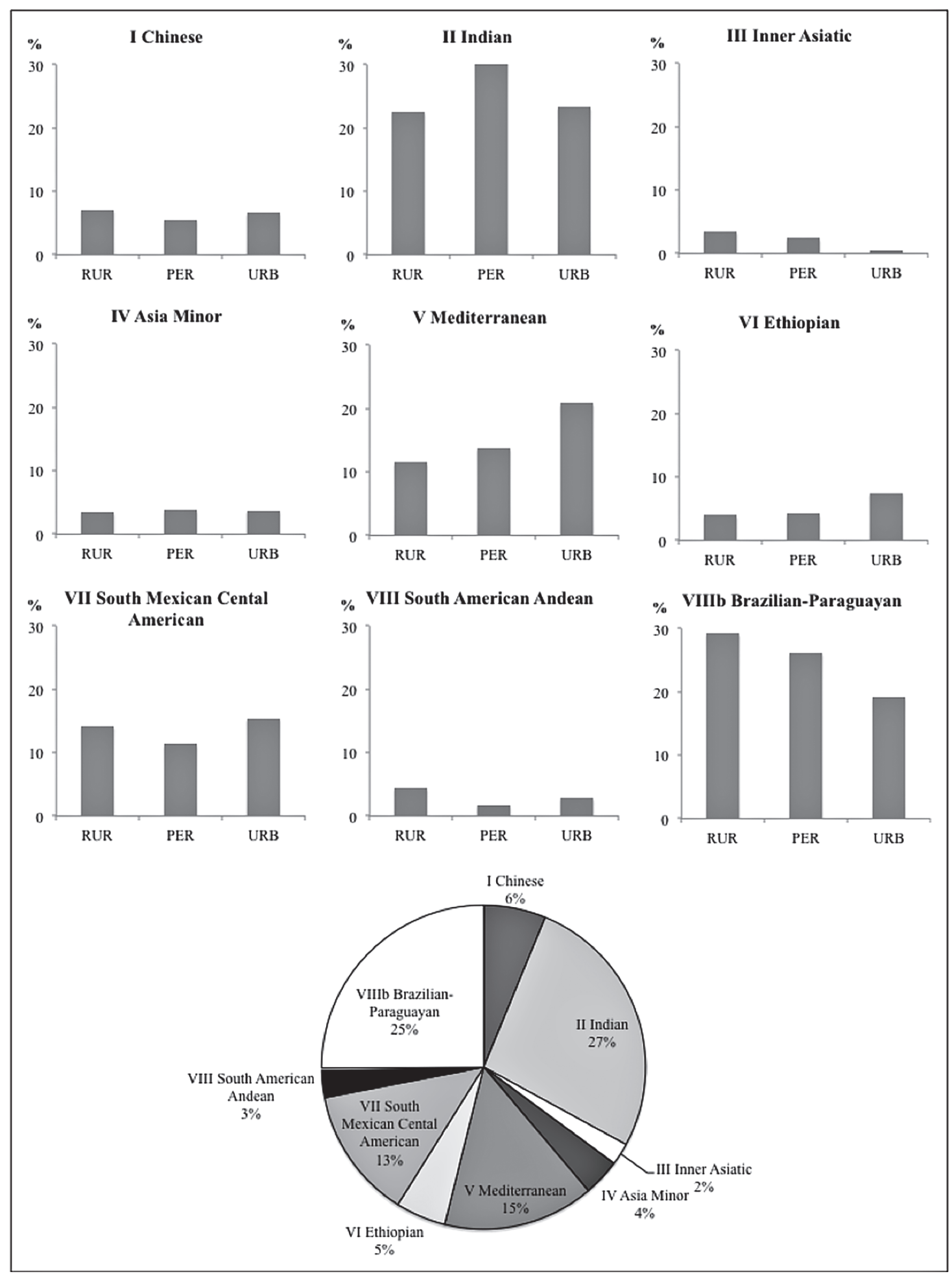

Figure 2. Biogeographic origins for the food plants in Santa Catarina Island homegardens ( $\mathrm{n}=109$ homegardens). Data in percentage. Biogeographic origin was classified based on Clement (1999), see text for further details. URB=Urban, PER=Periurban, RUR=Rural. 
Table 5. Native and introduced species in studied homegardens at Santa Catarina Island, Brazil ( $n=109)$.

\begin{tabular}{l|l|l|l|l}
\hline & Total & Urban & Periurban & Rural \\
\hline Richness of native species $(\%)$ & $38(38 \%)$ & $21(39 \%)$ & $26(37 \%)$ & $30(43 \%)$ \\
\hline Average natives per homegarden & $3.26(\mathrm{sd}=3.35)$ & $2.13(\mathrm{sd}=2.03)$ & $2.78(\mathrm{sd}=2.34)$ & $10.50(\mathrm{sd}=3.98)$ \\
\hline Richness of introduced species $(\%)$ & $61(62 \%)$ & $33(61 \%)$ & $45(63 \%)$ & $40(57 \%)$ \\
\hline Average introduced per homegarden & $5.45(\mathrm{sd}=4.33)$ & $4.31(\mathrm{sd}=2.84)$ & $4.95(\mathrm{sd}=3.71)$ & $12.90(\mathrm{sd}=5.61)$ \\
\hline
\end{tabular}

The Brazilian people are a result of a long process of miscegenation between local indigenous people, European (especially Portuguese) and African migrants (Ribeiro 1995), started mainly in $14^{\text {th }}$ century. This mixture had an expressive influence in Brazilian's culture, as well as in the way people use plants. Such transnational as well as internal migrations, as recent and past events, are important changing events in the knowledge systems and in the way people use resources (Ososki et al. 2007; Pieroni et al. 2012), once migration is a process responsible for exchanges of knowledge, cultural traditions and resources (Ososki et al. 2007). Several species of plants were introduced by European immigrants during the colonization period in Brazil. For example, the mango (Mangifera indica L.), natural from India, was introduced in Brazil after the period of the discovery of maritime commercial routes from Europe to Africa in 16th century (Silva 2006), with Portuguese navigations between Africa and Americas. Nowadays, Brazil is one of the main producers and exporters of introduced crops such as mango and Citrus, cultivated in all Brazilian states.

At the same time that migration makes people vulnerable to unknown situations, it can be seen as an opportunity to experience the new. This can be expressed in trying and experimenting plants, and recognizing the value of new resources (Medeiros et al. 2012). The knowledge systems are also affected by adaptation to the new environments, since people may create strategies of use and acquisition of plant resources (Medeiros et al. 2012). In this sense, plant cultivation in familiar areas, such as homegardens, can figure as an important alternative to knowledge and resources maintenance. In a study about Indian immigrants living in USA (Palaniswamy 2007), the maintenance of culturally important plants, native from their place of origin, was observed in migrants' homegardens.
In this context, homegardens can be understood as places where knowledge is practiced and exchanged, as redoubt areas, which express life stories of both plants and humans. In Florianópolis, homegardens can express the cultural multiplicity of local people, as a reflect of the Brazilian culture with mixed origins.

In addition, homegardens are important links between households, because they can constitute spaces for building networks for exchanges of products and species. These network exchanges have been documented in different places and with different scales of analysis (Heckler 2004; Lamont et al. 1999; Reyes-Garcia et al. 2013; Winklerprins 2002). We observed that seedlings and seeds used to propagate species were originated from exchanges between relatives and neighbors $(28 \%)$, or were so ancient that their keepers were not sure about their origin, being reproduced within the homegardens and constituting their own resources (34\%). Only $34 \%$ of the propagules were bought in local markets. Also, the weak interaction with the surrounding vegetation, especially in URB and PER, is reflected in the low percentages of seedlings or seeds from such places: only $4 \%$ were collected from surrounding environments. Since we analysed food species only, we can hypothesize that there is a low availability of these species in the surrounding areas to fulfil this need. In the whole context, in Florianopolis, the exchange of plants and propagules can also bring diversification to the composition of homegardens, making them important areas for conservation of non-native plants.

\section{CONCLUSIONS}

We observed that periurban homegardens are mostly maintained by younger people that recently arrived to live in the location. This is an indicator of 
areas in recent process of expansion. Homegarden size varied among the urbanization gradient: urban homegardens are smaller than rural and periurban ones, and rural homegardens are proportionally bigger than both other classes. Also, we observed comparatively higher species richness cultivated in the rural plots. In a micro-regional scale, the lack of strong contrasts between urban and periurban homegardens reflects the connections between them. In a more localized scale, the urbanization degree has a weak influence in shaping contrasting groups of periurban and urban homegardens, but even considering a small sample of rural homegardens there are marked contrasts between rural and other homegardens.

The most frequent species found in homegardens are herbaceous, corresponding to plants used as seasonings. This pattern shows the weak role of local homegardens in contributing for food security, since there are few staple foods grown. However, the importance of spices, herbs and seasonings as vitamin sources (Etkin 1994) that cannot be disregarded. Thus, the studied homegardens are systems with a few but important tree species. The maintenance of these species is fundamental to keep the dynamic processes of in situ and on farm conservation of native trees. There is also a predominance of the view of homegardens as models in scale of agroforestry systems, which reproduces parts of natural vegetation in its interior. Our results showed that this is a rough view of homegardens in areas such as south Brazil, where homegardens with a mixed composition of herbs/trees and native/introduced species can be found.

Most edible species grown in homegardens are introduced, representing the weak dependence on native species as a whole. Even so, homegardens can play a role on local conservation of some botanical families, such as Myrtaceae, an important family in Atlantic Forest, which includes several native tree fruits.

We observed the presence of plants from different origins and cultures in homegardens, which reflect constant material exchange between people, as well as the life histories of both peoples and plants, in the context of the effects of human migrations in plant distribution. In this sense, homegardens at Santa Catarina Island can be seen as agrobiodiversity reservoirs, constituting important places for agrobiodiversity conservation, as well as cultural maintenance.

\section{ACKNOWLEDGEMENTS}

We are grateful to the Brazilian agencies that provided financial support to this research: FAPESP 03/13688-9 (N.Peroni); FAPESP 04/02301-9 and 01/05263-2 and CNPq post doctoral scholarship (T. M. Miranda - PDJ 151321/2013-2); N. Hanazaki thanks UFSC/Funpesquisa for financial support. We are grateful to L. Cruz for help in data collection. Finally, we are very grateful to all interviewed people from Pântano do Sul, Costa de Dentro, Costa de Cima, and Sertão do Ribeirão.

\section{REFERENCES}

1. Akinnifesi FK, Sileshi GW, Ajayi OC, Akinnifesi Al, de Moura EG, Linhares JFP, Rodrigues I (2010) Biodiversity of the urban homegardens of São Luís city, Northeastern Brazil. Urban Ecosystems 13(1):129-146.

2. Albuquerque UP, Andrade LHC, Caballero J (2005) Structure and floristics of homegardens in Northeastern Brazil. Journal of Arid Environments 62:491-506.

3. Alcorn JB (1990) Indigenous agroforestry strategies meeting farmers' needs. In: Anderson $A B$ (ed) Alternatives to Deforestation: steps toward sustainable use of Amazon rainforest. Columbia University Press, New York, pp. 141-148

4. Amorozo MCM (2004) Pluralistic medical settings and medicinal plant use in rural communities, Mato Grosso, Brazil. Journal of Ethnobiology 24:139-161.

5. Anderson AB, Gely A, Strudwick J, Sobel GL, Pinto MGC (1985) Um sistema agroflorestal na várzea do estuário amazônico (Illha das Onças Município de Barcarena, estado do Pará). Acta Amazonica 15:195-224.

6. Badouin L, Lebrun P (2009) Coconut (Cocos nucifera L.) DNA studies support the hypothesis of an ancient Austronesian migration from Southeast Asia to America. Genetic Resources and Crop Evolution 56:257-262.

7. Baldoni L, Tosti N, Ricciolini C, Belaj A, Arcioni S, Pannelli G, Germana MA, Mulas M, Porceddu A (2006) Genetic structure of wild and cultivated olives in the central Mediterranean basin. Annals of Botany 98(5):935-42.

8. Batista KR (2004) Sertão do Peri: um olhar etnográfico. Percursos. Revista do Centro de Ciências da Educação 5(2).

9. Begossi A, Hanazaki N, Tamashiro JY (2002) Medicinal plants and the Atlantic Forest (Brazil): knowledge, use and conservation. Human Ecology 30:281-299.

10. Bernholt H, Kehlenbeck K, Gebauer J, Buerkert E (2009) Plant species richness and diversity in urban and peri-urban gardens of Niamey, Niger. Agroforestry Systems 77:159-179. 
11. Blanckaert I, Swennen RL, Flores MP, López RR, Saade RL (2004) Floristic composition, plant uses and management practices in homegardens of San Rafael Coxcatlán, Valley of TehuacánCuicatlán, Mexico. Journal of Arid Environments 57:39-62.

12. Breton C, Pinatel C, Medail F, Bonhomme F, Berville A (2008) Comparison between classical and Bayesian methods to investigate the history of olive cultivars using SSRpolymorphisms. Plant Science 175(4):524-532.

13. Brodt SB (2001) A systems perspective on the conservation and erosion of indigenous agricultural knowledge in central India. Human Ecology 29:99-120.

14. Brücher C (1989) Useful plants of Neotropical origin and their wild relatives. Springer Verlag, Berlin, DE

15. Buchmann C (2009) Cuban home gardens and their role in social-ecological resilience. Human Ecology 37:705-721.

16. Calvet-Mir L, Gómez-Baggethun E, Reyes-Garcia V (2012) Beyond food production: Ecosystem services provided by home gardens. A case study in Vall Fosca, Catalan Pyrenees, Northeastern Spain. Ecological Economics 74:153-160.

17. Clement C (1999) 1492 and the loss of Amazonian crop genetic resources. I. The relation between domestication and human population decline. Economic Botany 53:188-202.

18. Das T, Das AK (2005) Inventorying plant biodiversity in homegardens: A case study in Barak Valley, Assam, North East India. Current Science 89:155-163.

19. De Vries IM (1997) Origin and domestication of Lactuca sativa L. Genetic Resources and Crop Evolution 44:165-174.

20. Eichemberg MT, Amorozo MCM, Moura LC (2009) Species composition and plant use in old urban homegradens in Rio Claro, Southeast of Brazil. Acta Botanica Brasilica 23(4):1057-1075.

21. Etkin N (1994) Eating on the wild side: the pharmacologic, ecologic, and social implications of using noncultigens. The University of Arizona Press, Tucson, USA

22. Eyzaguirre P, Watson, J (2001) Home gardens and agrobiodiversity: an overview across regions. In: Watson JW, Eyzaguirre PB (eds) Home gardens and in situ conservation of plant genetic resources in farming systems. Proceedings of the Second International Home Gardens Workshop, 17-19 July 2001, Witzenhausen, Germany. IPGRI, Rome, 10-13

23. Fernandes ECM, Nair PKR (1986) An evaluation of the structure and function of tropical homegardens. Agroforestry Systems 21:279-310.

24. Galluzzi G, Eyzaguirre P, Negri V (2010) Home gardens: neglected hotspots of agro-biodiversity and cultural diversity. Biodiversity and Conservation 19:3635-3654.

25. Gaston KJ, Warren PH, Thompson K (2005) Urban domestic gardens (IV): the extent of the resource and its associated features. Biodiversity and Conservation 14:3327-3349.

26. Gotelli NJ, Entsminger GL (2011) EcoSim: Null models software for ecology. Version 7. VT 05465. Acquired Intelligence Inc. \& Kesey-Bear, Jericho, USA

27. Guillaumet JL, Grenand P, Bahri S, Grenand F, Lourd M, Santos AA, Gely A (1990) Le jardins-vergers familiaux d'Amazonie centrale: un example d'utilisation de l'espace. Turrialba 40:63-81.

28. Hanazaki N, Tamashiro JY, Leitão-Filho HF, Begossi A (2000) Diversity of plant uses in two Caiçara communities from the Atlantic Forest coast, Brazil. Biodiversity and Conservation 9:597-615.
29. Hanazaki N, Oliveira FC, Miranda TM, Peroni N (2009) Ethnobotany of artisanal fishers. In: Lopes PFM, Begossi A (eds) Current trends in Human Ecology. $1^{\text {st }}$ ed. Cambridge University Press, Cambridge, pp.104-124

30. Heckler SL (2004) Cultivating sociality: aesthetic factors in the composition and function of Piaroa homegardens. Journal of Ethnobiololgy 24:203-232.

31. IBGE Instituto Brasileiro de Geografia e Estatística (2016) Estimativa populacional. [http://www.cidades.ibge.gov.br/ xtras/perfil. php?lang $=\&$ codmun $=420540 \&$ search $=$ santacatarina|florianopolis] Accessed March 2016

32. Iorizzo M, Senalik DA, Ellison SL, Grzebelus D, Cavagnaro PF, Allender C, Brunet J, Spooner DM, Van Deynze A, Simon PW (2013) Genetic structure and domestication of carrot (Daucus carota Subsp. Sativus) (Apiaceae) 1. American Journal of Botany 100(5):930-938.

33. IPUF Instituto de Planejamento Urbano de Florianópolis (20092016) Geoprocessamento. [http://geo.pmf.sc.gov.br/geo_fpolis/] Accessed March 2016.

34. Janoo N, Grivet $L$, Seguin $M$, Paulet $F$, Domaingue $R$, Rao PS, Dookiun A, D'Hont A, Glaszmann JC (1999) Molecular investigation of genetic base of sugarcane cultivars. Theorical and Applied Genetics 99:171-184.

35. Jatoi SA, Kikuchi A, Mimura M, Yi SS, Watanabe KN (2008) Relationships of Zingiber species and genetic variability assessment in ginger (Zingiber officinale) accessions from ex-situ genebank, on-farm and rural markets. Breeding Science 58:261-270.

36. Kehlenbeck K, Maass BL (2004) Crop diversity and classification of homegardens in Central Sulawesi, Indonesia. Agroforestry Systems 63:53-62.

37. Kiær LP, Felber F, Flavell $A$, Guadagnuolo R, Guiatti $D$, Hauser TP, A. Olivieri AM, Scotti I, Syed N, Vishi M, van de Wiel C, Jørgensen RB (2009) Spontaneous gene flow and population structure in wild and cultivated chicory, Cichorium Intybus L. Genetic Resources and Crop Evolution 56(3):405-419.

38. Kumar BM, Nair PKR (2004) The enigma of tropical homegardens. Agroforestry Systems 61:135-152.

39. Lago MCS (1996) Modos de vida e identidade: Sujeitos no processo de urbanização da llha de Santa Catarina. Editora da UFSC, Florianópolis, SC, Brazil

40. Lamont SR, Eshbaugh WH, Greenberg AM (1999) Species composition, diversity, and use of homegardens among three Amazonian villages. Economic Botany 53:312-326.

41. Lorenzi H (1992a) Árvores brasileiras: manual de identificação e cultivo de plantas arbóreas nativas do Brasil. Volume 1. Plantarum, Nova Odessa, SP, Brazil

42. Lorenzi H (1992b) Árvores brasileiras: manual de identificação e cultivo de plantas arbóreas nativas do Brasil. Volume 2. Plantarum, Nova Odessa, SP, Brazil

43. Lorenzi H (1992c) Árvores brasileiras: manual de identificação e cultivo de plantas arbóreas nativas do Brasil. Volume 3 . Plantarum, Nova Odessa, SP, Brazil

44. Madaleno IM (2000) Urban Agriculture in Belém, Brazil. Cities 17:73-77.

45. Major J, Clement CR, Ditommaso A (2005) Influence of market orientation on food plant diversity of farms located on Amazonian dark earth in the region of Manaus, Amazonas, Brazil. Economic Botany 59:77-86. 
46. Medeiros PM, Soldati GT, Alencar NL, Vandebroek I, Pieroni A, Hanazaki N, Albuquerque UP (2012) The use of medicinal plants by migrant people: adaptation, maintenance, and replacement. Evidence-Based Complementary and Alternative Medicine 2012:1-11.

47. Meyer RS, DuVal AE, Jensen HR (2012) Patterns and processes in crop domestication: an historical review and quantitative analysis of 203 global food crops. New Phytologist 196(1):29-48

48. МОВOT Missouri Botanical Garden (2016) Tropicos. [http:// www.tropicos.org] Accessed March 2016

49. Nakata E, Staub JE, López-Sesé Al, Katzir N (2005) Genetic diversity of Japanese melon cultivars (Cucumis melo L.) as assessed by random amplified polymorphic DNA and simple sequence repeat markers. Genetic Resources and Crop Evolution 52:405-419.

50. Netting R (1977) Cultural ecology. Cummings Publishing Compani: Menlo Park, USA

51. Ososki AL, Balick MJ, Daly DC (2007) Medicinal plants and cultural variation across Dominican rural, urban and transnational landscapes. In: Pieroni A, Vandebroek I. (eds) Traveling cultures, plants and medicine: the ethnobiology and ethnopharmacy of human migrations. Berghahn Books, Oxford, 14-38

52. Padoch C, De Jong W (1991) The house gardens of Santa Rosa: diversity and variability in an Amazonian agricultural system. Economic Botany 45:166-175.

53. Palaniswamy UR (2007) The changing scene of health promotion and disease prevention strategies due to migration of Indians from the Asian Subcontinent to the United States. In: Pieroni A, Vandebroek I. (eds) Traveling cultures, plants and medicine: the ethnobiology and ethnopharmacy of human migrations. Berghahn Books, Oxford, 86-103.

54. Paton A, Putievsky E (1996) Taxonomic problems and cytotaxonomic relationships between and within varieties of Ocimum basilicum and related species (Labiatae). Kew Bulletin 51(3):509-524.

55. Pereira MA (2001) Diagnóstico físico e socioambiental do Parque Municipal da Lagoa do Peri, subsídios ao plano de manejo. MSc. Dissertation, Federal University of Santa Catarina, Florianópolis, SC, Brazil

56. Peroni N, Begossi A, Hanazaki N (2008) Artisanal fishers' ethnobotany: from plant diversity use to agrobiodiversity management. Environment, Development and Sustainability 10:623-637.

57. Peyre A, Guidal A, Wiersum KF, Bongers F (2006) Dynamics of homegarden structure and function in Kerala, India. Agroforestry Systems 66:101-115.

58. Pickersgill B (2007) Domestication of plants in the Americas: insights from Mendelian and molecular genetics. Annals of Botany 100:925-940.

59. Pieroni A, Quave CL, Giusti MA, Papp N (2012) “We are Italians!": The hybrid ethnobotany of a venetian diaspora in eastern Romania. Human Ecology 40:435-451.

60. Poot-Pool WS, van der Wal H, Flores-Guido S, Pat-Fernández JM, Esparza-Olguín L (2015) Home Garden Agrobiodiversity Differentiates Along a Rural-Peri-Urban Gradient in Campeche, México. Economic Botany 69: 203-217.

61. Prance G, Nesbitt M (2005) The cultural history of plants. Routledge, New York, USA
62. Reyes-Garcia V, Molina JL, Calvet-Mir L, Aceituno-Mata L, Lastra JJ, Ontillera R, Parada M, Pardo-de-Santayana M, Rigat M, Vallès J, Garnatje, T (2013) "Tertius gaudens": germplasm exchange networks and agroecological knowledge among home gardeners in the lberian Peninsula. Journal of Ethnobiology and Ethnomedicine 9:53.

63. Ribeiro $D$ (1995) $O$ povo brasileiro: a formação e o sentido do Brasil. Companhia das Letras, São Paulo, SP, Brazil

64. Rodríguez-Ariza MO, Moya EM (2005) On the origin and domestication of Olea europaea L. (olive) in Andalucía, Spain, based on the biogeographical distribution of its finds. Vegetation History and Archaeobotany 14(4):551-561.

65. Sanjur Ol, Piperno DR, Andres TC, Wessel-Beaver L (2002) Phylogenetic relationships among domesticated and wild species of Cucurbita (Cucurbitaceae) inferred from a mitochondrial gene: Implications for crop plant evolution and areas of origin. Proceedings of the National Academy of Sciences of the United States of America 99(1):535-40.

66. Shajaat Ali AM (2005) Homegardens in smallholder farming systems: examples from Bangladesh. Human Ecology 33:245-270.

67. SIDRA Sistema IBGE de Recuperação Automática (2016) Censo Demográfico 2010. Características da População e dos Domicílios. [http://www.sidra.ibge.gov.br/cd/cd2010universo. asp?o=7\&i=P] Accessed March 2016

68. Silva MGC (2006) Florescimento e frutificação de mangueira (Mangifera indica L.) cv rosa promovidos por diferentes doses de paclobutrazol. MSc. Dissertation, State University of Southwestern Bahia, Vitória da Conquista, BA, Brazil

69. Siviero A, Delunardo TA, Haverroth M, Oliveira LC, Mendonça AMS (2011) Cultivo de espécies alimentares em quintais de Rio Branco, Acre, Brasil. Acta Botanica Brasilica 25(3):549-556.

70. Smith NJH (1996a) Effects of land-use systems on the use and conservation of biodiversity. In: Srivastava JP, Smith NJH, Forno DA (eds) Biodiversity and agricultural intensification: partners for development and conservation. World Bank, Washington DC.

71. Smith NJH (1996b) Homegardens as a springboard for agroforestry development in Amazonia. International Tree Crops Journal 9:11-30.

72. Sthapit B, Gautam R, Eyzaguirre $P(2004)$ The value of home gardens to small farmers. In: Gautam R, Sthapit B, Shrestha $P$ (eds) Home Gardens in Nepal: Proceedings of a national workshop, 6-7 August 2004, Pokhara, Nepal. LI-BIRD, Pokhara, Nepal, 9-16

73. Sunwar S, Thomstrom CG, Subedi A, Bystrom M (2006) Home gardens in western Nepal: opportunities and challenges for on-farm management of agrobiodiversity. Biodiversity and Conservation 15:4211-4238.

74. United Nations (2004) World urbanization prospects: the 2003 revision. [http://www.un.org/esa/population/publications/ wup2003/WUP2003Report.pdf] Accessed April 2016

75. Vavilov NI (1992) Origin and geography of cultivated plants (First published in 1926 in Novoye v Agronomii (News in Agronomy). Cambrige University Press, Cambridge, UK

76. Vieira R, Grayer R, Paton A, Simon J (2001) Genetic diversity of Ocimum gratissimum $\mathrm{L}$. based on volatile oil constituents, flavonoids and RAPD markers. Biochemical Systematics and Ecology 29(3):287-304.

77. Vlkova M, Polesny Z, Verner V, Banout J, Dvorak M, Havlik J, Lojka B, Ehl P, Krausova J (2011) Ethnobotanical knowledge and 
agrobiodiversity in subsistence farming: case study of home gardens in Phong My commune, central Vietnam. Genetic Resources and Crop Evolution 58:629-644.

78. Watson JW, Eyzaguirre PB (2001) Home gardens and in situ conservation of plant genetic resources in farming systems. Proceedings of the Second International Home Gardens Workshop, 17-19 July 2001, Witzenhausen, Germany. IPGRI, Rome

79. Winklerprins AMGA (2002) Seasonal floodplain-upland migration along the lower Amazon river. Geographical Review 92:415-431. 